\title{
CULTURALLY PATTERNED SPEAKING PRACTICES - THE ANALYSIS OF COMMUNICATIVE GENRES ${ }^{1}$
}

\author{
Susanne Günthner and Hubert Knoblauch
}

\section{Introduction}

In the last few years studies within the Sociology of Language and Communication ${ }^{2}$ as well as within Anthropological Linguistics ${ }^{3}$ have repeatedly addressed the issue of communicative genres. Various empirical investigations on genres demonstrated that this concept proves to be a useful analytical tool with respect to the description of communicative patterns in everyday interactions.

On the basis of a broad review of this research, the present article aims at outlining the sociological approach to genre analysis, pointing out some relevant analytical categories which allow for a structural description of genres and thereby demonstrate the significance of this research for the analysis of communicative contexts and cultural speaking practices.

We shall argue that the analysis of communicative genres allows not only for the description and explanation of certain communicative activities in detail, but by establishing an essential analytic link between speaking activities in the ongoing interaction, the sociocultural context and the communicative budget (including communicative norms, expectations, ideologies etc.) of a particular culture, it also goes far beyond the task of classifying discursive activities: It mediates between situatively produced texts and larger sociocultural contexts. ${ }^{4}$ We shall demonstrate that the Sociology of Knowledge may provide a useful theoretical framework by linking detailed analyses of verbal activities with cultural speaking practices and communicative conventions.

\section{The genre traditions}

Genres of communication have been of interest to various disciplines: Classical

\footnotetext{
${ }^{1}$ We would like to thank Thomas Luckmann and John Gumperz for their valuable comments on an earlier version of this paper. Parts of this paper are based on Günthner/Knoblauch (1994).

2 Cf. Luckmann (1986; 1987; 1988; 1992), Bergmann (1994), Knoblauch (1991a), Bergmann/Luckmann (1995).

${ }^{3}$ Cf. Hanks (1987), Briggs/Bauman (1992).

${ }^{4}$ Cf. Hanks (1989).
} 
rhetoric as well as poetics, theology and literary criticism, all have been based on genre-concepts. These concepts have mainly been preoccupied with written texts (with few exceptions, e.g. the seminal work of Lord (1945/65)), whereas the work of Bakhtin (1979/86) and Volosinov (1929/86) prompted a 'communicative turn' in genre theory starting in the 1960 s. For Volosinov and Bakhtin, language is primarily located in the very communicative interaction in which it is produced, and it is realized by means of concrete utterances which vary according to the activity involved. The tight connection between language and social reality is based on the fact that language is used within typical social situations (Bakhtin 1979/86). Speaking occurs in speech genres which guide the interaction and which are determined by social structures.

\begin{abstract}
"Speech genres organize our speech in almost the same way as grammatical (syntactical) forms do. We learn to cast our speech in generic forms and, when hearing others' speech, we guess its genres from the very first words; we predict a certain length [...] and a certain compositional structure; we foresee the end; that is, from the very beginning we have a sense of the speech whole, which is only later differentiated during the speech process". (Bakhtin 1979/86: 78f.)
\end{abstract}

Seen from Bakhtin's perspective, genres do not appear as complex language structures devoid of the dynamics of interaction but rather as interactive patterns of speech. They not only guide the activities in verbal interaction but are also part of the ideologies of social groups. Bakhtin's conception of genres, which he divides into the classes of "simple genres" of everyday communication and "complex genres" (such as novels, dramas, essays), goes beyond a formal de scription of texts. He opposes a static concept of genre which opts for stylistic purism and exclusiveness. ${ }^{5}$

Within the social science tradition, research on genres has been prominent in folklore. Founded by the Brothers Grimm in the early 19th century, folklore studies regard genres as products of everyday communication to be analyzed in their own right. Folklorists catalogued and classified genres according to very different criteria, ${ }^{6}$ three of these seem to be crucial for ongoing research: a) Thematical types and "motifs" (Aarne/Thompson 1971) were taken as criteria for classifying genres (especially fairy tales) in different societies. This kind of classification (as e.g. in Thompson's collection 1955-59), however, was criticized for its ethnocentric stance as well as for imposing an "ideal order" on mundane conversation. The critique, formulated by von Sydow and Propp among others, led to b) a formal structural division of genres into ideal or real types (Honko 1968). Genres are either conceived of as more or less separate forms which may be arranged by the researcher according to idealized categories; or they are conceived as real types characterized by certain structures and morphologies. Thus, the sequential structure of texts is

\footnotetext{
${ }^{5}$ Within this context, we cannot elaborate on the Bakhtinian approach in detail; it must suffice to say that it is integrated in the approach to be sketched. Research based on Volosinov and Bakhtin have been taken up in several academic disciplines, as e.g., in folklore, linguistics, anthropology, sociology; even some currents within rhetoric that have come to account for the interactive character of genres refer to Bakhtin and Volosinov (Miller 1984).

${ }^{6}$ Such as context, form, structure, frequency, location, audience etc. Cf. Röhrich (1988), Honko (1987: 752).
} 
based on paradigmatical, latent structures (Propp 1988) (also known as cognitive models in other theories). c) The definition of genres according to functions originally assumed that genres may be distinguished according to different cultural spheres. Genres were regarded as typical expressions of human experience, as e.g. by Jolles' (1930/1982) who differentiated the 'simple forms' (einfache Formen) according to nine different 'mental activities' (Geistesbeschäftigungen ) corresponding to nine different spheres of meaning. These spheres of meaning were assumed to correspond to basic human needs and thus correlated to archetypal forms: Sacred: Legend; family: Age; creation: Myth; inquisition: Riddle; experience: Saying; moral: Casus; fact: Memorabile; naive morals: Fairy tale; the comical: Joke. In a similar vein, Malinowski (1960) stressed the sociocultural function of folklore genres. He saw folklore genres as contributing to the maintenance and survival of cultural groups as they serve important social and spiritual needs. In recent folklore studies, forms beside fairy tales, legends, anecdotes etc. are moving into the focus of research. Such forms are e.g. memorates, exemplary stories (Bausinger 1980), biographical reminiscences (Lehmann 1983), justificatory stories (Lehmann 1980) as well as genres especially adapted to the modern life-world, e.g. urban legends (Brunvard 1981). The meaning of genres is no longer reduced to textual features. Instead progressively the social context, the Sitz im Leben (Gunkel 1933) is considered to be constitutive for the analysis of folklore genres. ${ }^{?}$

The analysis of communicative genres has been of continuous interest for linguistic anthropology (and anthropological linguistics) since Boas' (1917/1940) seminal work. Early research focused on the problem of classification of oral genres: Sapir (1909), for instance, collected Wishram texts, according to categories such as "myth, customs, letters, non-mythical narratives, and supplementary upper Chinookan texts". The compilation and classification of these texts led to the discussion of formal and stylistic criteria that would distinguish genres, and for quite some time, anthropological linguistics tried to refine formal structures of singular genres (Briggs/Bauman 1992). However, the collected texts were rarely analyzed in their interactional contexts; instead genres were considered as fixed objects until the Ethnography of Communication (and the concomitant turn towards the dialogicity of communication) in the 1960 s started to have an impact on this strand of research. Gumperz and Hymes (1972) decidedly opted for the investigation of language use in contexts. Hymes $(1972,1974)$ viewed genres as an integral part of the communicative budget of a community. ${ }^{8}$ Despite the lack of theoretical conceptualization of "genres", the Ethnography of Communication has prompted a broad array of empirical investigations which take genre as the analytical focus for classifying verbal practices within different speech communities. Within this research, there is an obvious tendency to consider genres no longer as static, monological

\footnotetext{
${ }^{7}$ Cf. Oring (1986: 134-5).
}

${ }^{8}$ The notion of genres, however, lacks precision: Whereas, in "Models of the Interaction of Language and Social Life" Hymes (1972: 65) claims that "all speech has formal characteristics of some sort of manifestation of genres", in "Ways of Speaking" (1974: 443-444) he reaches the conclusion "that communities differ" according to the portion of speech which "is generically organized" and the portion that is more spontaneous and "thus escapes generic regimentation and why." 
products, but rather to adopt a performance-centered approach to genres, which meets Sherzer's (1987) demand for a "discourse-centered approach to language and culture". In combining Bakhtin's "sociological poetics" with Bourdieu's theory of practice, Hanks (1987) offers a new framework for the analysis of genres, regarding genres as "orienting frameworks, interpretative procedures and sets of expectations that are not part of discourse structure, but are part of the ways actors relate to and use language". The relationship between genres, speaking practices and social order is also addressed by Briggs/Bauman (1992), who - by referring to Bakhtin's concept of intertextuality - concentrate on the intertextual relations constituted by the use of genres in discourse.

Within linguistics, the research of Labov (1972) on stories prompted an expanding field of studies on narration demonstrating the role of different forms of stories within various institutional and private contexts. For quite some time, however, traditional text linguistics tended to apply terms deriving from analyses of written texts, such as "text sort" and "text type", to oral discourses. Their aim was to characterize textual types according to grammatical-stylistical features and text sorts according to 'situations of use' (Redekonstellationstypen) (Gutenberg 1981: 144). These notions, however, were modelled on monological, written texts without taking into account the dynamic interactive constitution of texts in social interactions. Influenced by the Ethnography of Communication, Interactive Sociolinguistics (Gumperz 1982) as well as by the Sociology of Knowledge, the notion of communicative genres is becoming increasingly accepted in linguistic analysis of discourse (Gülich 1986, Günthner 1993a; Kotthoff 1993a; 1995). This acceptance is paralleled by a new methodological orientation: Instead of taking oral genres as monological static texts, communicative genres are analyzed in the process of their interactive production, i.e. in their conversational and sociocultural context.

By stressing the dialogical character of communicative processes, Conversation Analysis has had an important influence on genre research. The quest for an analysis of social action in 'natural settings' is due to the repeated methodological demands of Harvey Sacks (1963) and his colleagues: To record and protocol social action empirically as a phenomenon in its own right. Finally, the analysis of conversational sequences led to the question how 'long' interaction sequences are intertwined. However, up to now conversation analysists have only investigated a few longer sequences. For instance, Jefferson/Lee (1981) demonstrated how "trouble talk" is organized into several stages which are collaboratively produced by the coparticipants. Bergmann's (1993a) analysis of gossip as a reconstructive genre as well as his study of emergency calls to the fire brigades (1993b) convincingly exemplifies how conversation analytic methods can be productively combined with the study of communicative genres. Goodwin's (1990) study of interactive processes among Black children in Philadelphia, which integrated methods of conversation analysis with those of ethnography of communication, sees verbal "activities" as being the relevant units for investigation. Her detailed analysis, concentrating on specific "activities" (which show generic patternings), such as arguments, gossip-disputes, instigating and stories shows how this specific group of urban Black children constitute their social world through verbal genres and activities. 


\section{A theoretical conceptualization of communicative genres}

The way communicative genres are treated within the Sociology of Knowledge (Berger/Luckmann 1966) provides us with a theoretical conceptualization of "genres". In the early 80s Bergmann and Luckmann (1983) developed an approach of genre analysis which takes into account the traditions of genre research mentioned above and links the notion of genre to the theoretical model of Social Constructivism within the Sociology of Knowledge. Even if we cannot elaborate here the (widely renown) approach of the "social construction of reality", we shall sketch the notion of genre within this theoretical framework; moreover we shall propose some new conceptualizations and methodological refinements which will be outlined on the basis of various empirical studies. ${ }^{9}$

According to Luckmann (1992a), communicative genres fulfil a more crucial function than just representing one possible "component of a speech event" - as Hymes (1974) has claimed. They represent central communicative means in the construction of social reality. Since socially constructed institutions and the corresponding legitimations (or "ideologies"; Bakhtin 1979/86) depend on the mediation and transmission of knowledge, the communicative processes by which this knowledge is transmitted to the individual are of crucial importance. The social stocks of knowledge - which are the resource for most of the objectified knowledge taken for granted within a given society - are being built up, maintained, transmitted and also modified in communicative processes. Whereas many communicative processes are produced on a spontaneous basis, some processes of communicative transmission of knowledge are fixed into genres. This means that the composition of a series of communicative elements and the various possibilities of its implementation are prepatterned. Communicative processes that follow such fixed patterns are called "genres". In this way, the notion of "genre" is neither reduced to literary or oral poetic genres nor do we claim, as Bakhtin appears to claim, that there is no communication outside of genres.

Communicative genres fulfil important functions with respect to the coping with, transmission and traditionalization of intersubjective experiences of the lifeworld. On the one hand, they facilitate the transmission of knowledge by guiding the interactants' expectations about what is to be said (and done). On the other hand, they are the sediments of socially relevant communicative processes, as only those processes may be expected to be fixed into genres which are of some relevance to the social actors. The assumption that communicative action is routinized into such prearranged patterns has serious consequences for the concept of communication itself. The transmission of socially relevant knowledge - one of the preconditions of the socialization of individuals - relies on conventionalized mediating patterns, i.e. communicative genres. Thus, wherever socially relevant knowledge is to be transmitted we find "convention" instead of "communicative rationality": Communication is subject to routinization which leads to convention in the same way that routinization leads to constitution with respect to social problems. ${ }^{10}$ Because

\footnotetext{
${ }^{9}$ Some of these studies have been prompted by this approach to genres.

${ }^{10}$ Cf. Berger/Luckmann (1966).
} 
speakers as well as recipients are familiar with genres they may be regarded as frames for the orientation that interactants refer to in producing, as well as interpreting, communicative action. If, for instance, a speaker begins an utterance by 'Did you hear the one about', a certain genre is contextualized and specific expectations arise on the recipient's part. Thus, the knowledge that communicative processes with specific functions occurring in certain social situations take on recurrent forms, not only guides the communicative actions themselves but also their interpretations. To the degree that the prefabrication of communicative patterns guides the interactants' expectations about the course of the communicative action, predefined genres facilitate the co-ordination of communicative actions. Therefore, the function of communicative genres may be seen as taking the burden away from the actors (i.e. relieving them ("Entlastung")) of having to co-ordinate every communicative action anew. ${ }^{11}$ By way of routinization, these interactive tasks become "non-problematic" and speakers may concentrate on other tasks. Genres are generated as soon as communicative interactants are faced with recurring problems which are of great relevance to the actors. Thus, genres are not only a 'model for' communicative action; they are also a 'model of' socially relevant communication. They constitute the communicative 'loci' or commonplaces of certain social categories, milieus, and classes, thereby mediating between speaking practices, social structure and culture. However, the social distribution of genre-related knowledge may be unequally distributed among the members, according to various criteria, such as gender, age, social position, caste etc. An essential element of genre-related knowledge is knowledge about the appropriate use of genres, i.e. when to use or not to use what genre. As Luckmann (1992a: 226) points out,

\begin{abstract}
"the use of genres is normally linked to clearly defined types of social situations. A given genre may never appear in one type of communicative situation, rarely in another, frequently in still another, and always in some. From the point of view of the actor's knowledge there may be situations in which he is forced to use a particular communicative genre, others in which the matter is optional and he is merely likely to do so, and still others in which he will rigorously avoid its use."
\end{abstract}

As historical and cultural products, communicative genres are, however, open to change and cultural variation. If we take communicative genres as socially constructed solutions which organize, routinize, and standardize the dealing with particular communicative problems, it seems quite obvious that different cultures may construct different solutions for specific communicative problems. Moreover, whereas in one culture there may be generic ways of handling particular communicative activities, in another culture interactants may use spontaneous forms instead. Thus, the repertoire of communicative genres vary from culture to culture as well as from one epoch to another.

The specific function of a communicative genre thus consists of providing solutions to specific problems of communicative action (Bergmann/Luckmann 1995). In gossiping, the interactants have to solve the problem of "discreet indiscretion"

11 "Relief" or "Entlastung" as a consequence of the process of routinization is described by Gehlen (1961) within the German tradition of Philosophical Anthropology. Cf. also Berger/Luckmann (1966) for a short English sketch of this approach. 
(Bergmann 1993a). In reproaching someone, the interactants solve the problem of one person evaluating a specific behavior or action of another person as being inadequate, wrong or immoral and demanding an explanation (Günthner 1993b). Exemplary stories demonstrate the validity of a statement or an evaluation by way of illustrating a specific case (Keppler 1988; Günthner 1993c), and interactive teachings set the task of resolving specific forms of asymmetries of knowledge (Keppler/Luckmann 1991). Levinson's (1979) notion of "activity" is useful for the specification of the function communicative genres. A certain activity, such as asking a student questions during an oral exam, can be done by means of various communicative forms or genres which may be more or less conventionalized and more or less prepatterned.

The functions of communicative genres should be distinguished from individual action goals. If, in a specific situation, a person intends to tell a joke in order to compromise another person, this goal must be compatible with the entertaining function of jokes, but not identical. The function of an interactive teaching sequence consists in levelling off asymmetries of knowledge. Yet, at the same time it may be strategically used as a way of impressing someone. Thus, genres may be reframed strategically: I may tell a joke in order to tease my participant instead of entertaining her. Such reframing, however, only succeeds if one assumes that there are prefixed communicative patterns.

Instead of taking the context as given, the analysis of communicative genres is based on a reflexive notion of context as used in Interpretative Sociolinguistics. Communicative genres are not just determined by social contexts but also contribute to the very constitution of these contexts. This concept implies that interactants construe context in carrying out their interactive activities: By using a certain genre the interactants enact a context for the interpretation of this particular activity (Gumperz 1982; Auer 1992).

The importance of communicative genres has to be seen in light of the growing importance of communicative processes for the functioning of society: To the degree that situations proliferate in which persons have to interact who do not know each other and do not share the same cultural conventions of communication. The growing social relevance of communication is tantamount to the increasing differentiation of the social stock of knowledge and the corresponding differentiation of social institutions and social milieus (Schütz/Luckmann 1984; Habermas 1981). In the face of this increasing pluralization, however, communication does not become more rational, as Habermas (1981) suggests; on the basis of the relief function of communication, rather, a growth and differentiation of communicative conventions is to be expected. The more crucial recurrent communicative problems become for typical social actors - as e.g. in democratic decision making, in self-presentation or testimonies, - the more likely becomes a growing routinization of the pertinent communicative processes.

These theoretical ideas on communicative genres are not the result of mere speculation. In fact, they result from a growing body of empirical research which proves the usefulness of the concept of communicative genre. Before sketching the empirical evidence, we shall outline three important analytical criteria. We shall first (a) propose a working definition of genres, (b) sketch its structural elements and (c) explain its methodological status, before presenting the constitutive elements of communicative genres in more detail. 
a) Functionally, communicative genres can be defined as historically and culturally specific, prepatterned and complex solutions to recurrent communicative problems. By prepatterned we refer to the observation that the occurrence of a certain feature of communicative actions makes the occurrence of another feature expectable or predictable. As the production of one action entails a preference for the production of another one, one may speak of a fixed pattern of action. Prepatterning thus, is based on the shared expectation of the steps of actions to succeed. Which features of communication come to be prepatterned and which steps of actions are to be expected, depends on cultural norms and values. Not living up to shared expectations may bring on sanctions, as can be seen in reparation procedures and corrective exchanges.

b) Structurally, a genre may be defined as a complex communicative pattern of elements which can be located on three different structural levels: ${ }^{12}$ The level of internal structure, the situative level and the level of external structure. The internal structure of a genre consists of:

"overall patterns of diverse elements, such as words and phrases, registers, formulas and
formulaic blocs, rhetorical figures and tropes, stylistic devices (metrics, rhyme, lists,
oppositions), prosodic melodies, specific regulations of dialogicity, repair strategies and
prescriptions for topics and topical areas." (Luckmann 1992b: 39; our translation, S.G./H.K.)

The external structure of communicative genres also exhibits a certain degree of obligation, that is, constraints with respect to milieus, the communicative situation, the type of the social relationship as well as social categories of actors (men, women, ethnic groups), relevant in such environments. Whereas the internal structure is comprised of linguistic signs of communicative action and the external structure of the "situated" elements referring to the institutional structure of a society, the situative level of communicative genres consists of those elements which are part of the ongoing interaction, i.e. the "interaction order". ${ }^{13}$ This includes the interactive exchange of utterances between different actors as well as the situative, sociospatial relation established by means of this interaction.

Generic forms consist of a combination of features to be expected, located on all three structural levels and thus form highly complex communicative patterns. Complexity refers to the combination of different recurrent elements. ${ }^{14}$ Whereas a sequence of interactive teaching or the exchange of compliments may be comprised of only a few recurrent features, gossiping - as described by Bergmann (1993a) - consists of a combination of lexical, prosodic, rhetoric devices, situative elements, particular organizational features and particular interactive roles (as the

12 Concerning the status of the "structural features", we should point out that what is at work is an indexical association of talk to context.

${ }^{13}$ For the difference between situated and situational cf. Erving Goffman (1983b).

14 This corresponds to the vertical co-occurrence rule, according to which the occurrence of a specific syntactical form is linked to e.g. a specific lexical choice and a certain prosodic register. Cf. Ervin-Tripp (1986: 233). 
gossip producer, the recipient and the subject of gossip). The more elements are part of the "form", the more complex a genre appears. Complexity can be enforced by the canonization of genres, that is, the institutionalization or even prescription of the form (Luckmann 1987).

Yet, the degree of complexity is likely to vary. Therefore we should speak of "communicative patterns" when referring to any fixed or crystallized communicative form regardless of its degree of complexity. If one intends to analyze communicative genres, one also has to take such patterns into account. Each community disposes of a large repertoire of communicative patterns (as in interactive teachings, having an argument, counselling in radio phone-in programs, or indignation stories) which show some kind of crystallization and complexity without representing what we call "prototypical genres". The question might come up, what degree of complexity is necessary and sufficient to speak of a "genre" instead of a "mere pattern". Surely, the boundaries are fluid. Of course, there are what we call prototypical genres - as for instance, the lamenting of Greek women analyzed by Caraveli-Chaves (1980) or the genealogical recitations of Bantu-kingdoms described by Albert (1972) - which have an obligatory character and are perceivably fixed and patterned with respect to situation, function and procedural structures. Now, in order to distinguish prototypical communicative genres from less fixed communicative patterns, one could say that prototypical genres are first of all highly complex with respect to syntagmatic as well as paradigmatic features. Moreover, they are characterized by some specific recurrent features, which are located at all three levels (the level of internal structure, the situative level and the level of the external structure). Furthermore, prototypical genres are characterized by a certain contour of beginning, middle and end. For instance, toasting in Caucasian Georgia has a ritualized beginning where the "tamada" (the toastmaster) stands up, holding a glass of some kind of alcoholic beverage and starts to address the audience in a ritualized way. The course of toasting follows a variable thematic canon accommodated to the specific situation at hand (a marriage, birth etc.). The formula "gaumardzos", the clinking of glasses, and the emptying of one's glass signal the end of the toast. (Kotthoff in press).

c) Whereas the notion of genres serves as a sensitizing concept for research, it has to be stressed that any patterned communicative action is a valuable subject for genre analysis. Before we start to describe the structural elements on all three levels in detail, it should be noted that the social stock of knowledge often provides everyday categories ("first order constructs", Schutz 1962) for communicative genres. However, there is no clear-cut correspondence between ethnocategories and genres. ${ }^{15}$ In German, for instance, we find the ethnocategory Vorwurf ('reproach'); however, as an analysis of reproaching reveals (Günthner 1993b), they may take on a whole array of different communicative forms, ranging from fixed patterns which are characterized by specific structural elements (Was -format, modal particles, extreme case formulations, extreme fluctuations in pitch contour, falling intonation at the end of the utterance etc.,) to utterances characterized only by a "reproaching"

${ }^{15}$ Cf. Silverstein $(1985 ; 1993)$ on metapragmatic categories, folk-metapragmatic discourse and the limits of native speakers' awareness of their language and its significance for linguistic research. 
prosody. Furthermore, interactants often refer metapragmatically to the ethnocategory (des soll jetzt kein VORWURF sein aber ich find du GEHSCH au unHEIMlich stark auf sie ein. 'I am not reproaching you but I think you give far too much attention to her') and thereby distance themselves from the interpretation of their following activity as a Vorwurf, although the utterance at hand shows typical reproach indicators and leads to remedial reactions (e.g. justifications, explanations, counter-reproaches etc.).

Furthermore, generic ethnocategories are not necessarily mutually exclusive nor consistent; they show much overlapping and social as well as regional variations. Even if the knowledge about genres is highly articulated in the social stock of knowledge - often by way of folk-taxonomies and folk-theories - this theoretical knowledge ("know what") must not necessarily coincide with the knowledge of use ("know how"). Theoretical elements of older forms e.g. may survive in the collective memory, and newer genres in status nascendi may not yet be part of folk-taxonomies (Luckmann 1992b: 23). As Swales (1990: 54f.) points out in his analysis of written academic genres, ethnocategories sometimes persevere against a background of substantial change in the activity, for instance, "lectures" in academic life nowadays are no longer the monologic recitations they once were, but include discussion and students working in small groups. "Tutorials" may no longer involve a tutor in the traditional sense, but may consist of student interaction with a computer program.

One should emphasize that communicative genres are not to be considered Sprechwerke, i.e. as static products to be described by their structural features only; rather, genres are constructed within communicative actions. This dynamic aspect of communicative genres may be expressed by the notion of "performance" as used in linguistic anthropology. As opposed to traditional folklore approaches, which analyze genres in a form purified of the context of their production, we argue that the elements of their communicative construction are to be considered as constitutive features of the genres themselves: The actors' voices, the relationship among the coparticipants, the sequential organization, the cultural context as well as its dramaturgic structure (Abrahams 1976). Thus, in order to analyze communicative genres, it does not suffice to just describe the internal and external features of isolated genres, one also has to take into account the dialogical principles and methods used to realize a particular genre in the specific situational context.

In analyzing the natural data by way of structural elements, we reconstruct what had been produced holistically by the actors as a kind of "second order construct" (Schutz 1962: 3ff.); i.e. the notion of "structure" refers to the scientific reconstruction of "first order constructs" (Schutz 1962: 3ff.), and thus, of what had already been produced and interpreted by the actors.

\section{Structural features of genres}

As mentioned above, three levels of analysis of communicative genres are distinguishable. We shall now describe these levels in some detail. 


\subsection{The internal structure}

The internal structure of communicative genres consists of verbal and prosodic (and kinetic) features characterizing single utterances or shorter sequences of utterances. Up to now, few investigations of prosodic features (such as loudness, tempo, pausing, intonation, rhythm, accent placement ${ }^{16}$ and features of voice quality ${ }^{17}$ of conversational genres have been undertaken, although prosodic phenomena - such as a "reproachful" prosody (Günthner in press), prosodic markers of indignation (Christmann 1993; Günthner 1993c) or prosodic features in 'rappin' and soundin' (Abrahams 1974) - have proven to be constitutive elements of certain communicative genres and patterns. Expressive signs, mimic and gesticulatory elements are also part of the repertoire of the internal structure. ${ }^{18}$ Lexico-semantic elements, such as a specialized vocabulary, archaic terms, euphemisms or derogatory words, certain modality markers, specific particles etc. can also make up part of the internal structure of a genre. Morpho-syntactic devices (such as question-formats, specific word order phenomena ${ }^{19}$, imperatives, passive constructions, specific conjunctions or "discourse markers") as well as phonological devices may function as constitutive elements of a particular genre. In addition, the selection of a specific linguistic variety or code may be determinative for a specific genre or for elements of the genre (such as citations, dialogism, indirect speech). Code features can be subdivided into jargon, dialect, sociolect, as well as the selection of a situationally apt register (frozen style, formal, consultative, informal or intimate register; Gläser 1976). In his study of Kuna speech genres, Sherzer (1974) describes the specific code in $n a$ makke, i.e. chants occurring in the village congress house. In this genre, speakers use a particular linguistic variety (sakla kaye or konkreso kaya), which can be distinguished from colloquial Kuna with respect to phonology (certain vowels occur which are usually elided in colloquial speech), morpho-syntax (certain "linking" morphemes are used whereas, noun and verb phrases are regularly deleted) and lexicon (specific words which are either not used or which have different meanings in everyday speech are employed).

Forms of patterning on the level of the internal structure may also include stylistic and rhetoric figures, concerning the way words are combined (asyndeton, polysynteton), deleted (ellipsis, aposiopese), added (accumulation, amplification, gradation), positioned (parallelism, chiasm), as well as the use of metaphors, metonymies, hyperbolas and other stylistic (litotes, emphasis, symbol etc.) or sound

${ }^{16}$ Cf. e.g. Selting (1992) on the function of intonation to contextualize different activities and genres; Couper-Kuhlen (1992) on speech rhythm in repair sequences; Erickson on the rhythmic organization in listing sequences. For the interactive relevance of such prosodic devices cf. CouperKuhlen/Selting (in press).

${ }^{17}$ Cf. Winkler (1986).

${ }^{18} \mathrm{Cf}$. Heath (1986) on body movement in medical consultation.

${ }^{19} \mathrm{Cf}$. Auer's (1993) analysis of verb-initial positioning reveals that the beginning of certain communication genres (e.g. jokes) in German is contextualized by verb-first-phrases (such as, "Kommt Fritzchen in die Schule..."; 'Comes little Fritz to school...'). 
figures (anaphora, epiphora, onomatopoetic forms etc.) (Müller 1989). ${ }^{20}$

Quite a number of communicative genres reveal specific "folk aesthetic principles" (Dundes/Leach/Özkök 1972), including a wide range of stylistic devices, such as specific rhyme patterns, melodic contours, the use of rhetoric figures, a particular vocabulary, an archaic syntax etc. In verbal duelling among Turkish boys, for instance, the performers use their verbal and rhetoric skills in order to choose topics appropriate in that context, to build on weaknesses in opponents' arguments, to create a witty response to an initial attack, to seize upon an actual or alleged "mistake" in the attacker's previous insult, to take part of the previous utterance as the point of departure for the continuation of the duel and to stick to certain rhythmic schemes (Dundes/Leach/Özkök 1972). Because aesthetic principles are a significant component in ritual duelling and insulting genres in general (Abrahams 1962; Labov 1972; Mitchell-Kernan 1972; Kotthoff 1995), speakers are judged according to their ability to perform.

Apart from those prosodic, mimic-gestical, lexico-semantic, morpho-syntactic, rhetoric and stylistic elements, 'minor forms' - such as stereotypes, idioms, common places, proverbs, formulas, riddles and inscriptions - can also provide constitutive elements of communicative genres. These minor or minimal forms differ from elaborate genres in so far as they can be integrated in more comprehensive forms; and moreover, they cannot be attributed to a definite function. For instance, the function of idioms (as topic termination, indirect criticism, as reconfirming general norms and values, or as entertainment) may be defined only with respect to the sequential organization of the particular idiom or the social context in which this form is used. Complex genres, on the other hand, do fulfil specific functions: Women's lamentos in Eastern Georgia which are built of several constitutive elements (specific rhythm, addressing the deceased etc.) as well as certain minimal forms (such as stylized wailing, specific idioms) function to express the community-binding mourning of women and to reproduce and confirm common moral values and norms (Kotthoff 1993a).

Dispositional elements and superstructures (Van Dijk 1978) also represent complex internal features of communicative genres, as e.g. the classical rhetorical "dispositio" (dividing the classical oration in "exordium, "narratio", "argumentatio" and "peroratio"). These superstructures provide a rough grid guiding the interactants' actions. For instance, Labov (1972) identifies a narrative model, dividing narration into specific phases: "abstract", "orientation", "complicating action" and "evaluation", "resolution" and "coda". Similarly, Ulmer (1988) distinguishes different temporal phases of conversion stories in everyday talk: A longer stretch of biographical time is portrayed in a condensed way, leading up to a temporally short event that contains many details. After this focused event, the 'subsequent' biographical time is again condensed. The temporal structure, characterized by the use of tempus (and the relation between narrated time and time of the narration), plays a decisive role for the constitution of these conversion stories.

Finally, "content" features may turn out to be elements of the internal

${ }^{20}$ Cf. Keenan's (1974) description of "kabary" performances in a Malagasy community: Here elaborate metaphors, traditional sayings and forms of indirection are used in order to avoid open conflict and also to demonstrate one's rhetoric ability. 
structure of communicative genres. "Content" here refers to various aspects, ranging from topics and topical fields (e.g. motifs of fairy tales, legends or stories of miracles as shown by folklorists), to "figures" (cf. Goffman 1986) appearing in the genre (such as the king or princess in fairy tales, representatives of certain ethnic groups in jokes or talking animals in fables), to figures' actions and even to the scenario of the events reproduced.

The framing of communicative genres - e.g. as fictional, ironic, playful, irrealis or realistic - is a further structural feature on the internal level. In teasing, for instance, a slightly aggressive and sometimes even hostile message is framed as "playful" and thus carries the metamessage of "rapport" (Straehle 1993; Günthner 1994a). As coined by Goffman (1981), the notion of framing ${ }^{21}$ not only refers to the specific interactive modality (or "keying") but includes the "production format", i.e. the speakers' relation to their utterances as "animators" (i.e. reproducers of utterances), as "authors" (i.e. producers of utterances), or as "principals" (i.e. the one who is responsible for the utterance). Forms of addressing - such as rhetorical 'forms of appeal' (Lausberg 1960) rhetorical question, sermocinatio, aporia - as well as recipient design formats constitute further framing elements. Thus, callers frame their messages on answering machines with respect to the social relationship they assumedly have shared with the person called, as e.g. intimate, informal or institutional (AlvarezCaccamo/Knoblauch 1992). The features of framing concerning the relation between speaker and coparticipant, are subsumed under the notion of "footing" (Goffman 1986). Footing or changes of footing function as contextualization cues (Gumperz 1982; Auer 1992) signalling the specific activities performed.

In order to analyze communicative genres, one also has to take into account the specificity of the medium. Keppler (1985) shows how media genres, such as the news, are characterized by a specific combination of verbal, visual and sound elements. On and off texts, animated pictures, colors and light are to be considered as well as camera positions, cuts, dramaturgy, figures and setting.

The selection of the elements of the internal structure fixed to various degrees of obligation. However, the degree of obligation always lies above that of spontaneous talk.

\subsection{The situative level of communicative genres}

The elements outlined above, which are located in what we call the internal structure of communicative genres, have to be distinguished from the interactive context, based on the dialogicity of utterances between multiple participants. Although the elements of the internal structures can be discerned in dialogical, conversational utterances, the very fact that utterances are dialogically produced by and distributed among different participants gives rise to a particular stratum of features which deserves special consideration, and consequently, a separate level of analysis. This situative level, first of all, is comprised of ritual phenomena, such as the opening and termination of interactive contacts, greeting and farewell rituals, rituals of inviting and accepting, etc. (Goffman 1981). Beside these rituals, features

\footnotetext{
${ }^{21}$ Cf. also Tannen (1993).
} 
concerning the interactive organization of conversation - as described by conversation analysists - are an integral part of this analytic level. These features can be described by patterns of turn-taking, pair sequences (adjacency pairs, as questions and answers, summons and responses). Strategies with regard to longer stretches of conversation are also part of the situative structure, e.g. in announcing a longer sequence of talk and getting a "ticket" as in narratives.

Some of these conversational elements may even be found in supposedly monologic genres; sales speeches, for example, exhibit elements of the interaction between speaker and audience which are constitutive for this genre (Basgöz 1975; Atkinson 1984). Within the 'rhetorical' situation, recipients are not only 'implicit actors' (Iser 1972); but they act (laugh, clap their hands, give signs of astonishment etc.) in response to certain patterns of action which are restricted by the genre and the social context of the situation (such as church ceremonies, carnival, political speech etc.) (Knoblauch 1987).

The conversational level of the situative structure - including phenomena, such as pair sequences, preference structures, the organisation of turns, pre-, post- and side-sequences - has been the subject-matter of Conversation Analysis. Phenomena, such -have been described by Conversation Analysis. Communicative genres frequently show particular constraints regarding their sequential organization. As Bergmann (1993a: 81) demonstrates, the initiation of gossip within an ongoing conversation is characterized by a presequence in which the interactants check whether the conditions necessary for gossiping are fulfilled: If the absent subject of gossip is mutually known to all participants and if all are willing to cooperate in this morally sensitive and socially reproved genre. Once these conditions are clarified, the actual gossip may start.

Although the analysis of communicative genres highly profits from the detailed studies of conversational organization within Conversation Analysis, we do not regard preference structures as part of the conversational apparatus but rather as conventions which heavily depend on the socio-cultural context. Thus, for instance, Pomerantz (1984) assumes that there is "a general dispreference for disagreement" in everyday conversations, whereas we would argue that this seemingly "general dispreference for disagreement" is a culturally specific (white middle-class-North American) and a socially contextualized (small talk situations) convention. This can be supported by Schiffrin's (1984) analysis of Philadelphia Jewish argumentation styles which display a preference for the production of disagreement. Similar results, demonstrating a preference for direct, unmitigated disagreements were obtained with respect to other social and cultural contexts (German-American, GermanChinese, Swabian, Black American children), and with respect to specific genres (informal discussions, playing in the street) (Goodwin 1990; Knoblauch 1991a; Günthner 1993a; Kotthoff 1993b).

Further dimensions of the situative structure have been pointed out by Goffman (1983a): Participation framework; longer stretches of talk and non-linguistic environment of the social situation. The participation framework is constituted by the production format as well as the participation status. Since the production format refers to the relation of the speaker to the proposition communicated or to the figure portrayed, we take it to be an element of the internal structure. Participation status refers to the portrayed relation between the communicating participants and their utterances: Speaker and listener, teacher and pupil, objects or producers of 
gossip, etc. Ulmer (1988: 21) analyzed the participation format with respect to conversion stories and demonstrated that the way these stories are told strongly depends on how the participants relate to their participation status as a 'member of a religious group'. As Bergmann's (1993a: 49) analysis of gossip shows, gossping consists of the gossip subject, the gossip recipient and the gossip producer. The gossip subject is distinguished from the other two figures by her/his status: S/he is present only as someone who is being gossiped about. This negative determination of the subject of gossip, however, forms a constitutive feature of this genre, as "it is essential that anyone who is the subject of gossip be absent". To give another example: When reconstructing reproaches, narrators can take over the interactive role of the former producer of the reproach ("and I went: Why the hell did you have to treat him like this!") as well as the former addressee of the reproach ("the only thing she can do is reproach me over and over again: Can't you come on time. Can't you dress neatly..."). The specific participation status (as producer or addressee) turns out to be relevant for the reproach reproduced: Speakers tend to reconstruct their own reproaches as justified, whereas reproaches from someone else directed at the present speaker, are frequently reconstructed as unjustified, exaggerated and hysterical (Günthner 1993b).

Participation frameworks may last only for several turns, as for instance in producing an 'interactive teaching' session (Keppler/Luckmann 1991) participants take on for a short period of time the roles of a 'teacher' and a 'pupil' (that is, the one taught in the communicative situation). Participation frameworks, however, can also last for a longer stretch of communicative sequences which, thereby, provide the situational "co-text" of the single utterances and their sequencing. In his study of customers at a German "kiosk", Schmitt (1992) demonstrates how actors, by routinely producing specific communicative forms in a certain style, show themselves to be specific communicative types. These 'presentational figures' are made up of communicative activities which are specific for each type and which thereby constitute lasting local identities of the setting. These communicative activities, of course, are established with respect to other figures present. In a similar vein, Goodwin's (1990) analysis of interaction among Black children documents how social relations are conventionalized (in a gendered way) by means of disputes, citations and stories.

Finally, the non-linguistic social arrangements are part of the situative structure of communicative patterns. This aspect involves situative elements as resources of communication. Especially the constellation of participants in "the microecology of situation" plays an important role, i.e. the socio-spatial and temporal arrangement of interactants as well as the action patterns accompanying speaking. In medical encounters, for instance, these social arrangements are combined with speech in a rather standardized way (ten Have 1989). The genre of toasting in Caucasian Georgia, for instance, is always connected to a specific social arrangement, including guests being present, a meal being served and above all, alcohol being on the table (Kotthoff in press).

The spatial and temporal settings that are characterized by aggregations of genres and patterns and by a personal of social types may be called a "social occasion". Hence, "social occasion" refers to structured or even institutionalized actions that are bounded in space and time; e.g. "public criticism meetings", which became very popular during the Cultural Revolution in China represent such a "social 
occasion". These meetings were organized in a very formalized way, the verbal (the singing of revolutionary songs, shouting of particular slogans, criticizing the accused 'monsters and demons') and non-verbal (standing up, sitting down, bringing the accused on stage etc.) activities being strictly prescribed. (Yuan/Kuiper/Shaogu 1990). Sherzer (1974) shows how the use of diverse genres (chiefs' chants, formal speeches, healing sermons) among the Kuna Indians are linked to different social occasions that exhibit specific participation statuses and involve the selection of certain social structural categories of actors (chiefs, women, youth). Duranti's (1984) study of speech genres on Samoa demonstrates that because there is an interrelationship between communicative genres and "social occasions", the analysis of lauga (an oratory genre, which is used in ceremonial events as well as in political meetings) can only be achieved by studying the organization of the social occasions in which lauga is used: Whereas, in political meetings lauga is used in a rather instrumentally oriented mode, in ceremonial events this genre happens to be a prototypical "performance event" with a display of great verbal virtuosity.

Social occasions may include formal (e.g. political meetings, ceremonial occasions, "gatekeeping situations" such as job interviews or examinations) as well as informal events (e.g. "family dinner situations"; Keppler (1994)). Elements located on the situative level are thus features which are produced in the ongoing interaction or which are at least accessible to direct manipulation. These elements are thus to be distinguished from what Goffman (1983b) calls "situated elements". Although "situated elements" become relevant in face-to-face interaction, they are derived from structural conditions, such as social inequality, power distribution or economic differences. Therefore, "situated elements" are located on - what we call the "external structure of communicative genres".

\subsection{The external structure of communicative genres}

The external structure consists of definitions of communicative milieus and communicative situations as well as the selection of types of actors (according to gender, age, status etc.) and the institutional distribution of genres (Luckmann $1992 b) .^{22}$

Communicative milieus, as e.g. families, women's groups, street gangs or student cliques, can be characterized by the fact that a group of communicative actors participates in recurring social occasions. Thus, ethnic milieus whose members participate in recurring social occasions are characterized by their repertoire of speaking practices and communicative genres. Various ethnographic studies of speaking practices among Blacks in the USA reveal the significance of genres, such

22 Cf. also Bakhtin (1979/86: 62) who pointed out, elements situated on the external structure may also be constitutive of certain patterns and genres: "Any research whose material is concrete language - the history of language, normative grammar, the compilation of any kind of dictionary, the stylistics of language and so forth - inevitably deals with concrete utterances (written and oral) belonging to various spheres of human activity and communication: Chronicles, contracts, texts of laws, clerical and other documents, various literary, scientific, and commentarial genres, official and personal letters, rejoinders in everyday dialogue (...) and so on." 
as ritual insults and verbal duelling for many Black youth cultures (Kochman 1972). As research within Interpretative Sociolinguistics (Gumperz 1982; Erickson/Shultz 1982; Günthner 1993a) demonstrates, the characteristics of ethnic milieus cannot just be found on the level of internal and situative structures (e.g. the organisation of argumentation, prosodic features to signal new and given information, recipient signals etc.): The functions of genres and patterns vary too across ethnic milieus. In Chinese argumentation, for instance, proverbs and idioms fulfil an important function in the backing of arguments: They allow speakers to demonstrate their classical knowledge and to present their own assertions as being part of traditional and still valid collective wisdom. In intercultural communicative situations, however, not only clashes of various functions of communicative genres may appear but also differences in the assessment of particular genres. Whereas, in the Chinese context, to "ornate" one's argumentation, academic thesis or speech with quotes of proverbial sayings is highly valued and appreciated as a sign of good education, in the Western context books on style advise against using routine forms and proverbs (Günthner 1988; 1991).

Even if the notion of communicative milieus is in need of additional elaboration, it already provides us with the link between social structures and communicative activities. Gerhards (1992) describes the structures of social movements in Berlin as being based on particular social occasions (political meetings and gatherings). By analyzing the communicative budget of social occasions, such as meetings in the local group of the 'green' social movement Christmann (1992) demonstrated that the communicative interaction in these meetings provides the "material basis' of what emerges as a "movement" on the surface of the public media.

The external structure of genres also includes the selection of social categories of actors who have access to, are competent in or allowed to perform particular genres. In this respect, gender-related differences in the use of communicative genres play an important part in many communities (Günthner 1994b). The differential control of women and men over verbal resources and genres provide an important area of investigation, also in terms of the significance of the relationship they create between discourse production and reception by women and men, for the constitution of social power (Briggs 1992: 351; Gal 1989). In Caucasian Georgia, for example, the genre of "toasting" constitutes an important, ritualized male genre and a central means to construct "masculinity". Toasting activities may even lead to ritualized competitions among men. Those men at the table who lack rhetoric abilities of toasting "are considered unmanly" (Kotthoff in press). Whereas, in informal situations, women once in a while may take over the role of toast-masters, in formal situations the toast-master has to be a man. Women are traditionally in charge of preparing and serving the meals: They tend to stay in the kitchen, forming a separate and less formal conversation group, immersing themselves in their own informal talk.

Keenan (1974) demonstrates that in a Malagasy community there appears to be a clean division between the two sexes concerning the communicative genres they use. Whereas women are excluded from a major formal genre which is oratory; men are excluded from a series of speech activities that women engage in, such as gossip and accusations. The genres that are attributed according to gender are based on the prevailing ideologies of women's and men's speech behavior: Women 
are considered to be direct and confrontative, men indirect and respectful. Thus, by using language in gender-specific ways and using gendered genres, speakers embody and recreate salient stereotypes about the "nature" of women and men. ${ }^{23}$

Thus the repertoire of communicative genres available to women and men in a particular culture may be highly indexical concerning the prevailing gender ideologies (Günthner 1994b) ${ }^{24}$.

Next to social milieus and social categories, the institutional distribution of genres has turned out to be of particular analytical importance. The interactive relevance of narratives in the legal system was demonstrated by Bennett and Feldman (1981). Legal procedures rely on communicative competence to produce stories and make them plausible by a) identifying central story lines, b) portraying their relation to symbolic relations in a consistent way and c) in allowing a test of descriptive adequacy (Bennett 1979). The acceptability of legal claims seems to be measured in terms of the narrative plausibility which forms part of legal procedures, investigations, reports, and argumentation (Seibert 1991; Hoffmann 1991). ${ }^{25}$ The use of genres in Swahili law courts in coastal Kenya is explored by Hirsch (1992). Narratives, which are particularly associated with women's speaking practices and are negatively evaluated by the persisting ideology are mainly used by women and thus undercut their speech in divorce suits. In contrast to women's use of narratives, in which hardly any explicit evaluations of the presented events are uttered, men predominantly use non-narrative genres, in which they assess the presented events, provide interpretations for the judges and formulate abstract rules - phrased in the language of the Islamic law.

In his study of the Yakan concept of litigation, Frake (1972) specifies the place of various verbal genres within different speech situations. His description of hukum 'litigation' is embedded in an "ethnography of law" in this Philippine community.

Yuan/Kuiper/Shu's (1990) study of formulae during the Cultural Revolution

23 A similar opposition between kroses 'angry', a genre which is highly confrontational and which is associated with women, and "an oratory genre" used by men, focussing on social harmony and agreement is discussed by Kulick (1992) in his ethnography of speaking practices in a Gapun community (Papua New Guinea). What is revealing about these gendered genres (kroses versus oratories) is the fact that the obscenity-filled kross-making is negatively valued and speakers using "kroses" are seen to have an immature personality; men's oratories - in contrast - are positively valued and considered to be oriented to the well-being of the community. These two genres also function as indexes of gender-related characteristica: Whereas women are associated with individualism, atomicity and anti-social behavior, whose selfish actions constantly threaten the community, men are seen as sociable, generous and temperate (Kulick 1992: 287-288). As in the Malagasy society, men tend to inform their wives whenever there are infractions that they have been subjected to. The wives are then expected to perform kros and get publically angry. In doing so they reinforce the stereotype of women being quarrelsome and loud-mouthed.

${ }^{24}$ Cf. also Hartog (1992) who analyzes gender roles in genetic counselling sessions in Germany.

${ }^{25}$ Whereas most research in this field uses the notion of pattern of scheme, in other areas of research the notion of genre is more frequently referred to. This holds e.g. for research on oral and written forms of scientific communication (Swales 1990; Dubois 1988), and especially for religious communication. 
in China provides a revealing example of how socio-political changes may affect speaking practices and communicative genres in the realm of institutional settings. Before the Cultural revolution the class greeting in Chinese schools was highly ritualized. The teacher first greeted the students with the formula tongxuemen hao! ('students well'!) and the student responded by laoshi hao ('teacher well!'). This greeting ritual was accompanied by nonverbal activities: The students had to stand up and thus pay respect to the teacher. However, during the Cultural Revolution the traditional greeting formulae were replaced by the formula: Rang women jing zhu Mao zhuxi wanshouwuqiang! ('let us respectfully wish Mao chairman a long life!'). The first part of the expression rang women jing zhu Mao zhuxi was uttered by all the student monitor and the second part wan shouwuqiang was usually uttered three times by all students as well as by the teacher. This second part is a dated idiomatic expression and before the Cultural Revolution it was only used for the Emperor. After the Cultural Revolution and with China's "opening policy", however, the traditional way of greeting was reintroduced in this institutional context.

With respect to the religious institutional field, Gunkel's (1933) research already has shown that biblical psalms have to be investigated as genres of an oral folk culture, and that the knowledge about the social environment of their use, the Sitz im Leben, is a precondition for understanding them. Analyses of genres not only make the critical evaluation of texts possible (Honko 1968): More and more scholars share the opinion that the specificity of the "sacral" is most clearly expressed in language (Samarin 1987), and especially in the genres of religious communication, such as prayers, sermons, "holy words" etc. This does not only hold for written forms: Especially the New Religious Movements (which depend more on oral forms of communication) are characterized by phrases, formulas, sermons and other genres that exhibit specific features for each religious group (Zaretsky/Leone 1974). Religious genres are socially regulated forms solving the problem of reconstructing subjective experiences of transcendence (Luckmann 1991); the strong tendency of crystallization of religious knowledge in communicative genres - as e.g. by verbal forms of divinatory practices - results from the strong demand of societies to organize and control subjective experiences of transcendence (Luckmann 1990). The subjective experience of conversion, for instance, is regularly expressed by way of a socially available form of conversion story. In the description of their conversions, "converts seem to be guided by interpretation and interpretative schemes which have been mediated and bestowed to them by the religious group in which they are members" (Ulmer 1988). This necessity to objectify subjective experience by means of communicative patterns that render it plausible holds also for "paranormal experience" (Danielson 1983), stories on the second face (Virtanen 1976), reports on UFO-sightings (Degh 1977), miraculous healings (Knoblauch 1991b) etc.

Studies in political anthropology also have pointed out the relevance of communicative genres for the maintenance of political units. Especially in egalitarian societies which do not have specialized political institutions, political questions, decisions, and traditions are discussed and nego tiated in the course of village gatherings. Genres of political communication include ceremonial forms of speech, such as the sunmakke at political gatherings of the Kuna Indians (Sherzer 1974), the highly stylized ceremonial, exclusively male kabary at village gatherings on Madagas- 
car, or the informal poetical genres such as the kiyori among the Wana (Indonesia) (Atkinson 1984). Political speech genres exhibit specific features on the level of the internal structure; but their special function accrues by the social, temporal and spatial frame of the social occasions in which they are used and by which they are distinguished from other forms of every day talk (Duranti 1984).

Social structures also find expression in written genres, as for example in the "official" language documents produced in the 16th century colonial Yucatan. By invoking dominant (Spanish) ideological and institutional frameworks, the authors of these documents sustained the appearance that they shared the same values and norms as their Spanish colonizers. However, this framework is interspersed with many local Mayan discourse structures. Because of the influence of the Spanish colonial power, hybrids develop which mix Spanish and local Mayan elements (Hanks 1987).

Another example, of how social structures may give rise to particular genres, stems from China. During the Song-Dynasty (960-1279) in the province of Hunan a special "women's writing system" was developed, which has been used right up until the 20 th century exclusively by women. Women used this writing system for a specific genre, the "women's letters" (nüshu) which for centuries turned out to be a very common form of communication among women in certain parts of Hunan. When women married, they moved into their husbands' house and very often were extremely isolated from their own family and friends, nüshu had the function of keeping in touch with other women: In this genre women narrated their sorrowful experiences in the husband's family, offered comfort, provided help and created a female publicity. (Sternfeld 1990: 24ff.). Nüshu were written in the local dialect, using paper, cotton or fans as writing material. Thus, besides oral lamenting genres, this written genre was developed, to allow women who were very isolated from their families and friends to communicate their grievances and seek comfort.

The notion of genre also turns out to be useful in the analysis of media communication. Starting from Labov's scheme of narration, Montgomery (1991) identifies radio shows as discourse genres with fixed structures: The opening consisting of a frame and an focus; the second part of a complication, a closing, an orientation and an evaluation, leading to a coda, and the closing section consists of a resumé, a moral and a final framing. Alvarez-Caccamo/Knoblauch's (1992) analysis of communicative patterns in leaving messages on answering machines reveals that not only the outgoing messages are constituted by stereotypical features (greeting, identification, instruction etc.) resembling minimal forms (Wojcik $1987 / 88$ ), but also the incoming messages are organized according to certain patterns. Similar observations were made with respect to electronic mail (Murray 1988).

\section{Ethnotheory, linguistic ideology and the communicative budget}

In accordance with Hanks (1987) we argue that communicative genres can be treated as historically and culturally specific conventions and ideals according to which speakers compose talk and recipients interpret it. In choosing a particular genre, a speaker makes use of culturally segmented solutions to communicative problems, and at the same time - due to their prepatterning - genres not only "relieve" the speaker but also assist the recipients in limiting the interpretative 
possibilities of utterances by relating them to the specific genre. The orientation towards generic forms is an important component of inference processes in interaction.

By using a particular genre, interactants link their utterances to "generalized or abstracted models of discourse production and reception". Through this kind of linkage that Briggs/Bauman (1992: 147) - in applying Bakhtin's concept of intertextuality - describe as "intertextual relationship", texts are rendered as "ordered, unified, and bounded on the one hand, and fragmented, heterogeneous, and openended on the other". By reproducing a genre, a prior discourse becomes "recontextualized" and the speaker creates links to historical and social connections: That is, s/he recontextualizes these connections in the current discursive setting. However, genres may also be "decontexualized", that is, detached from their traditional contextual use (Bauman/Briggs 1990). The strategies used for creating generic links are affected by socio-cultural, political and ideological factors.

The interrelationship between generic speaking practices and social structures, values and ideologies may be detected by scrutinizing the prevailing "ethnotheories" of communication, i.e. members' explicit knowledge about communicative forms and practices. Irvine's (1979) study of speaking practices among the Wolof of Senegal illustrates the connection between ethnotheories of speaking and social structures in this male dominated and hierarchically organized community. In this society, rhetorical competence and talk ability are not esteemed among the high ranked status groups, as these abilities prove a person's low status. Keeping silent, on the other hand, is indicative of belonging to the high castes and aristocrats. The hierarchical order is produced (among other things) by speech: Men and women of lower ranks tend to talk a great deal, whereas aristocratic men hardly speak at all. The latter even hire professional speakers to take their roles in speaking. In Burundi, on the other hand, another caste society organized along strongly hierarchical lines, eloquence is highly esteemed (Albert 1972). Young boys of the upper caste start receiving speech training at the age of ten: They are taught an "elegant" vocabulary, "elegant" speaking manners, as well as receiving voice training and lessons in lyrics. Thus the rhetorical abilities turn out to be of some importance for the construction of social hierarchies (as between castes and gender). Ethnotheories concerning members' discourse practices (be it that men and members of the noble castes are seen as less talkative and less articulate as in the Wolof community, or as more talkative and articulate as in Burundi) are always to be interpreted in the context of the prevailing cultural conceptualization of adequate, appropriate and valued communicative behavior. Ethnotheories or members' knowledge about communicative means are thus closely connected to the concept of "linguistic ideology", that is "sets of beliefs about language articulated by users as a rationalization or justification or perceived language structure and use" (Silverstein 1985). The relationship between the culturally varying distribution of communicative patterns or genres and social practices is in a complex way related to those systems of ideas, interests and expectations through which members of a community interpret discursive strategies and communicative behavior (Irvine 1992). "Ideology" thus proves to be a fruitful concept as it suggests a connection between ideas about language and speaking practices with ideas about social status, appropriate conduct and power relations and thereby forms what Silverstein (1992: 320) calls culture-specific "metadiscourses": 


\begin{abstract}
"Such a metadiscourse is semiotically situated to advantage in being a mode of rationalizing explanation, representing de-contextualizable characteristics as the basis of how indexical signs instance types of meaningfulness. Thus, any account of how individuals recruited to the roles in semiotic events are indexed by certain linguistic forms, have this characteristic: Women vs. men engage in, or are skilled at, distinct genres of discourse - extensional observation - because, women are such-and-such and men are so-and-so-- intensionalization in another etiological schema giving the 'essence' of the social category; these are the valued vs. devalued forms of language because they are in keeping with tradition or the way of the ancestors or not - the Malinowskian 'charter myth' about indexically-pregnant forms; etc."
\end{abstract}

Linguistic ideologies determine the "relevance structures" (Schutz/Luckmann 1973) which give rise to the patterning of communication, to genres and similar forms. The investigation of the relation of linguistic ideologies, communicative patterns and social structures, however, demands an overarching concept. We would argue that the communicative budget - which is conceived as the totality of communicative processes influencing the permanence and changes of society - provides such a concept. It comprises the sum of communicative processes that are available to individual members, categories of actors, groups, milieus and institutions within a society (Luckmann 1988: 284). The communicative budget is not only a scientific container for the existing communicative forms in a particular culture. Similarly to the concept of "linguistic field" (Bourdieu 1991), it describes the social distribution of communicative forms, which is affected by the social relevance of communicative genres, ethnotheories and prevailing linguistic ideologies in a particular community. As the sketch of the external structure has shown, the communicative budget of modern societies is stratified according to different divisions: a) the dimension of social categories of typical communicators and their interrelationship (such as, menwomen; children-adults; experts-lay persons; members of a certain caste, class etc.); b) the institutional domain suggesting that there is a functional division in the communicative budget of modern societies so that 'similar' communicative problems are treated differently according to the specific institutional sphere (law, politics, science, religion etc.); c) segmentary milieu divisions which cut across various spheres (such as, family milieus, leisure groups, life-style milieus). All three divisions regulate the access of individuals to the means of communication and thus construct their communicative competence. As Bourdieu (1991) suggests, the access to a particular "field" - or in our terminology: To a social category, institutional domain and milieu - is a decisive criterion organizing the budget. According to Bourdieu (1991), the power of the words depends on the power of the speaker of the words, which is determined by her/his social location in a particular "field". In addition to this view, one should stress that the social location of the speaker is itself constructed communicatively to a large extent, as his/her access to a certain field is built up by communicative activities, i.e. by way of communicative forms, patterns and genres.

Admittedly, this sketch is but a rough outline. Yet, it allows to understand how genres are part of a cultural system of signs and have "value loadings, social distributions, and typical performance styles according to which they are shaped in the course of utterances" (Hanks 1987: 670). Thus, the analysis of communicative patterns and genres can prove to be an important link between language and culture, as in the actual production of utterances oriented to a specific genre, speakers not only produce culturally routinized conventions of communication but also reconfirm, recreate or modify typified organizational forms of communicative 
behavior.

\section{References}

Aarne, Antti \& Stith Thompson (1971) The types of the folk-tale. A classification and bibliography. New York: Burt Franklin.

Abrahams, Roger D. (1962) Playing the dozens. Journal of American Folklore 75.209-220.

Abrahams, Roger D. (1974) Talking on the streets. In R. Bauman \& J. Sherzer (eds.), Explorations in the Ethnography of Speaking. Cambridge: Cambridge University Press, 337-353.

Abrahams, Roger D. (1976) The complex relations of simple forms. In D. Ben Amos (ed.), Folklore genres. Austin: University of Texas Press, 194-214.

Albert, Ethel M. (1972) Culture patterning of speech behavior in Burundi. In J.J. Gumperz \& D. Hymes (eds.), Directions in sociolinguistics. The Ethnography of Communication. New York: Holt, Rinehart \& Winston Inc., 72-104.

Alvarez-Caccamo, Celso \& Hubert Knoblauch (1992) 'I was calling you'. Communicative patterns in leaving a message to an answering machine. Text 4:12.473-505.

Atkinson, Jane Monnig (1984) 'Wrapped Words': Poetry and politics among the Wana of Central Sulawesi, Indonesia. In D.L. Brenneis \& F. Myers (eds.), Dangerous words. Language and politics in the Pacific. New York: New York University Press, 33-68.

Auer, Peter (1992) Introduction: John Gumperz' approach to contextualization. In P. Auer \& A. di Luzio (eds.), The contextualization of language. Amsterdam: John Benjamins, 1-38.

Auer, Peter (1993) Zur Verbspitzenstellung im gesprochenen Deutsch. Deutsche Sprache 3.193-222.

Bakhtin, Mikhail M. (1976/86) The problem of speech genres. In C. Emerson \& M. Holquist (eds.), Speech genres and other essays. Austin: University of Texas Press, 60-102.

Basgöz, Ilhan (1975) The tale singer and his audience. In D. Ben-Amos \& K.S. Goldstein (eds.), Folklore, performance and communication. Paris: Mouton, 143-203.

Bauman, Richard (1983) Let your words be few. Symbolism of speaking and silence among seventeenth century Quakers. Cambridge: Cambridge University Press, 60-102.

Bauman, Richard \& Charles R. Briggs (1990) Poetics and performance as critical perspectives on language and social life. Annual Review of Anthropology 19.59-88.

Bausinger, Hermann (1980) Formen der Volkspoesie. Berlin: Erich Schmidt Verlag.

Ben-Amos, Dan (1976) Analytical categories and ethnic genres. In D. Ben-Amos (ed.), Folklore genres. Austin: University of Texas Press, 215-242.

Bennett, Lance W. (1979) Rhetorical transformation of evidence in criminal trials. Quarterly Journal of Speech 65.311-323.

Bennett, Lance W. \& Martha S. Feldman (1981) Reconstructing reality in the courtroom. Justice and judgement in American culture. New Brunswick: Rutgers University Press. 
Berger, Peter \& Thomas Luckmann (1966) The social construction of reality. Garden City, N.Y.: Doubleday Inc.

Bergmann, Jörg (1985) Flüchtigkeit und methodische Fixierung sozialer Wirklichkeit: Aufzeichnungen als Daten der interpretativen Soziologie. In W. Bon $\beta$ \& H. Hartmann (eds.), Entzauberte Wissenschaft: Zur Relativität und Geltung soziologischer Forschung. Göttingen: Otto Schwartz, 299-320.

Bergmann, Jörg (1990) On the local sensitivity of conversation. In I. Markova \& K. Foppa (eds.), The dynamics of dialogue. Hertfordshire: Harvester Wheatsheaf, 201-226.

Bergmann, Jörg (1991) Jenseits von Sequenz und Gattung: Die Analyse größerer kommunikativer Verlaufsbögen. Manuscript. Universität Konstanz.

Bergmann, Jörg (1993a) Discreet indiscretions. The social organization of gossip. New York: de Gruyter.

Bergmann, Jörg (1993b) Alarmiertes Verstehen: Kommunikation in Feuerwehrnotrufen. In Th. Jung \& S. Müller-Doohm (eds.),'Wirklichkeit' im Deutungsprozeß. Frankfurt: Suhrkamp, 283-328.

Bergmann, Jörg \& Thomas Luckmann (1983) Strukturen und Funktionen von rekonstruktiven Gattungen in der alltäglichen Kommunikation. Manuscript. Universität Konstanz (Antrag auf ein DFG-Projekt "Rekonstruktive Gattungen").

Bergmann, Jörg \& Thomas Luckmann (1995) Reconstructive genres of everyday communication. In U. Quasthoff (ed.), Aspects of oral communication. Berlin: de Gruyter, 289-304.

Boas, Franz (1917/1940) Race, language and culture. New York: Free Press.

Briggs, Charles L. (1992) 'Since I am a woman, I will chastise my relatives': Gender, reported speech, and the (re)production of social relations in Warao ritual wailing. American Ethnologist 19/2.337361.

Briggs, Charles L. \& Richard Bauman (1992) Genre, intertextuality, and social power. Journal of Linguistic Anthropology 2:2.131-172.

Bogatyrev, P. \& R. Jakobson (1972) Die Folklore als eine besondere Form des Schaffens. In H. Blumensath (ed.), Strukturalismus in der Literaturwissenschaft. Köln: Kiepenheuer \& Witsch, 13-24.

Bourdieu, Pierre (1991) Language and symbolic power. Cambridge: Polity Press.

Brenneis, Donald, L. (1984) Straight talk and swect talk: Political discourse in an occasionally egalitarian community. In D.L. Brenneis \& F. Myers (eds.), Dangerous words. Language and politics in the Pacific. New York: New York University Press, 69-84.

Bricker, Victoria R. (1974) The ethnographic context of some mayan speech genres. In R. Bauman \& J. Sherzer (eds.), Explorations in the ethnography of speaking. Cambridge: Cambridge University Press, $368-388$.

Brunvard, Jan Harold (1981) The vanishing hitchhiker. American urban legends and their meanings. New York/London: Norton.

Bude, Heinz (1991) Die Rekonstruktion kultureller Sinnsysteme. In U. Flick et al. (ed.), Handbuch Qualitative Sozialforschung. München: Psychologie Verlagsunion, 101-112. 
Burger, Harald (1990) Sprache der Massenmedien. Berlin/New York: de Gruyter.

Burke, Peter (1979) Back to Burkhardt. New York Review of Books 26:15.35-37.

Caraveli-Chaves, Anna (1980) Bridge between worlds. The Greek women's lament as communicative event. Journal of American Folklore 93.129-157.

Christmann, Gabriela B. (1992) Wege in Ökologie-Gruppen. Oder: Das 'Vokabular von 'Weil'Motiven' bei Akteuren der Umweltbewegung. BIOS, Zeitschrift für Biographieforschung und Oral History 2.189-212.

Christmann, Gabriela B. (1993) 'Und da hab ich wirklich so einen Zornesausbruch gekriegt ... .. Moral mit Affekt: Die moralische Entrüstung am Beispiel von Ökologie-Gruppen. Arbeitspapier Nr. 6. Universität Konstanz: Fachgruppe Soziologie.

Coulmas, Florian (1981) Routine im Gespräch. Zur pragmatischen Fundierung der Idiomatik. Wiesbaden: Athenäum.

Couper-Kuhlen, Elizabeth (1982) Contextualizing discourse: The prosody of interactive repair. In P. Auer \& A. di Luzio (eds.), The Contextualization of Language. Amsterdam: Benjamins, 337-364.

Couper-Kuhlen, Elizabeth \& Margret Selting (in press) Towards an interactional perspective on prosody and a prosodic perspective on interaction. To appear in E. Couper-Kuhlen \& M. Selting (eds.) Prosody in conversation. Interactional studies. Cambridge: Cambridge University Press.

Danielson, Larry (1983) Paranormal memorates in the American Vernacular. In H. Kerr \& Ch.L. Crow (eds.), The occult in America: New historical perspectives. Urbana Ill. \& Chicago: University Press, 196-217.

Degh, Linda (1977) UFO's and how folklorists should look at them. Fabula 18.242-248.

Dijk van, Teun (1978) Textwissenschaft. Eine interdisziplinäre Einführung. München: dtv.

Dubois, Betty Lou (1988) Genre and structure of biomedical speeches. Forum Linguisticum 5/2.140169.

Dundes, Alan (1966) Metafolklore and oral literary criticism. In The Monist 50.505-516.

Dundes, Alan, Jerry W. Leach \& Bora Özkök (1972) The strategy of Turkish boys' verbal dueling rhymes. In J.J. Gumperz \& D. Hymes (eds.), Directions in sociolinguistics. The Ethnography of Communication. New York: Holt, Rinehart and Winston Inc., 130-160.

Duranti, Alessandro (1984) Lauga and Talanoaga: Two speech genres in a Samoan political event. In D.L. Brenneis \& F. Myers (eds.), Dangerous words. Language and politics in the Pacific. New York: New York University Press, 217-237.

Erickson, Frederick (1992) 'They know all the lines': Rhythmic organization and contextualization in a conversational listing routine. In P. Auer \& A. di Luzio (eds.), The Contextualization of Language. Amsterdam: Benjamins, 365-397.

Erickson, Frederick \& Jeffrey Schultz (1982) The counselor as gatekeeper: Social and cultural organization of communication in counselling interviews. New York: Academic Press.

Ervin-Tripp, Susan (1972) On sociolinguistic rules: Alternation and co-occurrence. In J.J. Gumperz \& D. Hymes (eds.), Directions in sociolinguistics. The Ethnography of Communication. New York: 
Holt, Rinehart and Winston Inc., 213-250.

Frake, Charles (1972) 'Struck by speech': The Yakan concept of litigation. In J.J. Gumperz \& D. Hymes (eds.), Directions in sociolinguistics. The Ethnography of Communication. New York: Holt, Rinehart and Winston Inc., 106-129.

Gaik, Frank (1992) Radio talk-show therapy and the pragmatics of possible worlds. In A. Duranti \& Ch. Goodwin (eds.), Rethinking context. Language as an interactive phenomenon. Cambridge: Cambridge University Press, 271-289.

Gal, Susan (1989) Between speech and silence: The problematics of research on language and gender. IPrA Papers in Pragmatics 3:1.1-38.

Gehlen, Arnold (1961) Anthropologie. Reinbek: Rowohlt.

Gehlen, Arnold (1972) Der Mensch. Seine Natur und seine Stellung in der Welt. Wiesbaden: Akademische Verlaggemeinschaft Athenäum.

Gerhards, Jürgen (1992) Politische Veranstaltungen. Kölner Zeitschrift fürSoziologie und Sozialpsychologie 44:4.766-779.

Gläser, Rosemarie (1976) Die Stilkategorie 'Register' in soziolinguistischer Sicht. Zeitschrift für Phonetik, Sprachwissenschaft und Kommunikationsforschung 29.234-243.

Goffman, Erving (1981) Forms of talk. Philadephia: University of Pennsylvania Press.

Goffman, Erving (1983a) Felicity's condition. American Journal of Sociology 89.1-53.

Goffman, Erving (1983b) The interaction order. American Sociological Review 48.60-68.

Goffman, Erving (1986) Frame analysis: An essay on the organization of experience. Boston: Northeastern University Press.

Goodwin, Marjorie (1990) 'He-Said-She-Said'. Talk as social organization among Black children. Bloomington: Indiana University press.

Gossen, Gary H. (1972) Chamula genres of verbal behavior. In A. Paredes \& R. Bauman (eds.), Towards new perspectives in Folklore. Austin: University of Texas Press, 145-167.

Gossen, Gary H. (1974a) Chamulas in the world of the sun: Time and space in a Maya oral tradition. Cambridge, Mass.: Harvard University Press.

Gossen, Gary H. (1974b) To speak with a heated heart: Chamula canons of style and good performance. In R. Bauman \& J. Sherzer (eds.), Explorations in the Ethnography of Speaking. Cambridge: Cambridge University Press, 389-413.

Gülich, Elisabeth (1986) Textsorten in der Kommunikationspraxis. In W. Kallmeyer (ed.), Kommunikationstypologie. Düsseldorf: Schwann, 5-46.

Gumperz, John J. (1982) Discourse strategies. Cambridge: Cambridge University Press.

Gunkel, Hermann (1933) Einleitung in die Psalmen: Die Gattungen der religiösen Literatur Israels. Göttingen: Vandenhoecht \& Ruprecht.

Günthner, Susanne (1988) Interkulturelle Aspekte von Schreibstilen. In M. Lieber \& J. Posset 
(eds.), Texte Schreiben im Germanistik-Studium. München: Iudicium, 145-159.

Günthner, Susanne (1991) 'A language with taste': Uses of proverbial sayings in intercultural communication. Text 3.399-418.

Günthner, Susanne (1993a) Diskursstrategien in der Interkulturellen Kommunikation. Analysen deutschchinesischer Gespräche. Tübingen: Niemeyer.

Günthner, Susanne (1993b) Vorwürfe als Formen moralischer Kommunikation. Arbeitspapier Nr. 9. Universität Konstanz: Fachgruppe Soziologie.

Günthner, Susanne (1993c) Moralische Geschichten. Beispielerzählungen mit Einladungen zur moralischen Entrüstung. Arbeitspapier Nr. 5. Universität Konstanz: Fachgruppe Soziologie.

Günthner, Susanne (1994a) Zwischen Konfrontation und Spiel. Zur kommunikativen Konstruktion von Frotzeleien. Arbeitspapier Nr. 12. Universität Konstanz: Fachgruppe Soziologie.

Günthner, Susanne (1994b) Male and female speaking practices across cultures. To appear in M. Hellinger \& U. Ammon (eds.), Contrastive Sociolinguistics. Berlin: Mouton.

Günthner, Susanne (in press) Moral voices. The prosodic contextualization of reproaches in 'why'formats. To appear in E. Couper-Kuhlen \& M. Selting (eds.), Prosody in conversation. Interactional sudies. Cambridge: Cambridge University Press.

Günthner, Susanne \& Hubert Knoblauch (1995): 'Forms are the food of faith.' Gattungen als Muster kommunikativen Handelns. Kölner Zeitschrift für Soziologie und Sozialpsychologie 46:4.693-723.

Gutenberg, Norbert (1981) Formen des Sprechens. Gegenstandskonstitution und Methodologie der Gesprächs- und Redetypologie in Sprach- und Sprechwissenschaft. Göppingen: Kümmerle.

Habermas, Jürgen (1981) Theorie des kommunikativen Handelns. Bd. II. Frankfurt: Suhrkamp.

Hanks, William F. (1987) Discourse genres in a theory of practice. American Ethnologist 4:14. 668696.

Hanks, William F. (1989) Text and textuality. Annual Review of Anthropology 18.95-127.

Hartog, Jennifer (1992) Paare in der genetischen Beratung. In S. Günthner \& H. Kotthoff (eds.), Die Geschlechter im Gespräch. Kommunikation in Institutionen. Stuttgart: Metzler, 177-200.

Have, ten Paul (1989) The consultation as a genre. In B. Torode (ed.), Text and talk as social practice: discourse difference and division in speech and writing. Dordrecht: Foris, 115-135.

Heath, Christian (1986) Body movement and speech in medical interaction. Cambridge: Cambridge University Press.

Heller, Eva (1984) Wie Werbung wirkt: Theorien und Ursachen. Frankfurt: Fischer.

Hirsch, Susan F. (1991) Sprache und Geschlecht in Kenia. In S. Günthner \& H. Kotthoff (eds.), Von fremden Stimmen. Frankfurt: Suhrkamp, 261-290.

Hoffmann, Ludger (1991) Vom Ereignis zum Fall. Sprachliche Muster zur Darstellung und Überprüfung von Sachverhalten vor Gericht. In J. Schönert (ed.), Erzählte Kriminalität. Tübingen: Max Niemeyer, 87-113. 
Honko, Laurie (1968) Genre analysis in folkloristics and comparative religion. Temenos 3.48-66.

Honko, Laurie (1987) Gattungsprobleme. In Enzyklopädie des Märchens, Bd. 5, Berlin/New York: de Gruyter, 7-52.

Hymes, Dell (1972) Models of the interaction of language and social life. In J.J. Gumperz \& D. Hymes (eds.), Directions in sociolinguistics. The Ethnography of Communication. New York: Holt, Rinehart and Winston Inc., 35-71.

Hymes, Dell (1974) Ways of speaking. In R. Bauman \& J. Sherzer (eds), Explorations in the Ethnography of Speaking. Cambridge: Cambridge University Press, 433-451.

Irvine, Judith (1979) Formality and informality in communicative events. American Anthropologist 81.779-790.

Irvine, Judith (1992) Ideologies of honorific language. Pragmatics 2:3.251-262.

Iser, Wolfgang (1972) Der implizite Leser. München: UTB.

Jefferson, Gail \& John R.E. Lee (1981) The rejection of advice: Managing the problematic convergence of a 'trouble-telling' and a 'service encounter'. Journal of Pragmatics 5.399-422.

Jolles, Andre (1930/1982) Einfache Formen. Tübingen: Niemeyer.

Keenan, Elinor (1974) Norm-Makers, norm-breakers. In R. Bauman \& J. Sherzer (eds.), Explorations in the ethnography of speaking. Cambridge: Cambridge University Press, 125-143.

Keppler, Angela (1985) Präsentation und Information. Zur politischen Berichterstattung im Fernsehen. Tübingen: Narr.

Keppler, Angela (1987) Der Verlauf von Klatschgesprächen. Zeitschrift für Soziologie 16:4.288-302.

Keppler, Angela (1988) Beispiele in Gesprächen. Zeitschrift für Volkskunde 84:1.39-57.

Keppler, Angela (1994) Tischgespräche. Frankfurt: Suhrkamp.

Keppler, Angela \& Thomas Luckmann (1989) 'Weisheits'-vermittlung im Alltag. Wer in den Augen eines anderen weise ist, ist weise. In W. Oelmüller (ed.), Philosophie und Weisheit. Paderborn: Schöningh, 148-160.

Keppler, Angela \& Thomas Luckmann (1991) 'Teaching': Conversational transmission of knowledge. In I. Markova \& K. Foppa (eds.), Asymmetries in dialogue. Hertfordshire: Harvester Wheatsheaf, 14.3-165.

Keppler, Angela \& Thomas Luckmann (1992) Lebensweisheiten im Gespräch. In H.G. Petzold \& R. Kühn (eds.), Psychotherapie und Philosophie. Philosophie als Psychotherapie? Paderborn: Junfermann, 201-222.

Kloepfer, Rolf \& Hanne Landbeck (1991) Ästhetik der Werbung. Frankfurt: Suhrkamp.

Knoblauch, Hubert (1987) 'Bei mir ist lustige Werbung, lacht euch gesund' - Zur Rhetorik der Werbeveranstaltungen bei Kaffeefahrten. Zeitschrift für Soziologie 16:2.127-144.

Knoblauch, Hubert (1991a) The taming of foes. The avoidance of asymmetry in informal discussions. In 1. Markova \& K. Foppa (eds.), Asymmetries in dialogue. Hertfordshire: Harvester Wheatsheaf, 166- 
194.

Knoblauch, Hubert (1991b) Die Welt der Wünschelrutengünger und Pendler. Frankfurt/New York: Campus.

Knoblauch, Hubert (1994) Communio. Die kommunikative Konstruktion kultureller Kontexte. Habilitationsschrift: Universität Konstanz.

Kochman, Thomas (1972) 'Rappin' and stylin' out: Communication in urban Black America. Chicago: University of Illinois Press.

Köhler, Erich (1977) Gattungssystem und Gesellschaftssystem. Romanistische Zeitschrift für Literaturgeschichte 1.7-22.

Kosack, Wolfgang (1971) Der Gattungsbegriff 'Volkserzählung'. Fabula 12.18-47.

Kotthoff, Helga (1991) Der Tamada gibt bei Tisch den Ton an. In S. Günthner \& H. Kotthoff (eds.), Von fremden Stimmen: Weibliches und männliches Sprechen im Kulturvergleich. Frankfurt: Suhrkamp, 229-260.

Kotthoff, Helga (1993a) Weibliche Lamento-Kunst in Ostgeorgien. Georgica, Zeitschrift für Kultur, Sprache und Geschichte Georgiens und Kaukasiens 93.21-31.

Kotthoff, Helga (1993b) Disagreement and cohesion in disputes: On the context sensitivity and preference structures. Language in Society 22,193-216.

Kotthoff, Helga (1995) Verbal duelling in Caucasian Georgia. In U.M. Quasthoff (ed.), Aspects of oral communication. Berlin: de Gruyter, 112-137.

Kotthoff, Helga (in press) The social semiotics of Georgian toast performances. To appear in Journal of Pragmatics, 1995.

Kulick, Don (1992) Anger, gender, language shift and the politics of revelation in a Papuan New Guinean village. Pragmatics 2:3.281-297.

Labov, William (1972) The transformation of experience in narrative syntax. In W. Labov (ed.), Language in the Inner City: Studies in the Black English vernacular. Philadelphia: University of Pennsylvania Press, 354-396.

Lausberg, Heinrich (1960) Handbuch der literarischen Rhetorik. München: Max Hueber Verlag.

Lehmann, Albrecht (1980) Rechtfertigungsgeschichten Über die Funktion des Erzählens eigener Erlebrisse im Alltag. Fabula 21.56-69.

Lehmann, Albrecht (1983) Erzählstruktur und Lebenslauf. Autobiographische Untersuchungen. Frankfurt/New York: Campus.

Levinson, Stephen C. (1979) Activity types and language. Linguistics 17.356-399.

Lord, Albert B. (1945/65) Der Sänger erzählt. München: Carl Hanser.

Luckmann, Thomas (1986) Grundformen der gesellschaftlichen Vermittlung des Wissens: Kommunikative Gattungen. Kölner Zeitschrift für Soziologie und Sozialpsychologie, Sonderheft 27.191-211.

Luckmann, Thomas (1987) Kanon und Konversion. In A. Assman \& J. Assman (eds.), Kanon und 
Zensur. München: Fink, 38-46.

Luckmann, Thomas (1988) Kommunikative Gattungen im kommunikativen 'Haushalt' einer Gesellschaft. In G. Smolka-Kocrdt, P.M. Spangenberg \& D. Tillmann-Bartylla (eds.), Der Ursprung der Literatur. München: Wilhelm Fink Verlag, 279-288.

Luckmann, Thomas (1990) Shrinking transcendence, expanding religion? Sociological Analysis 51:2.127-138.

Luckmann, Thomas (1991) Die unsichtbare Religion. Frankfurt: Suhrkamp.

Luckmann, Thomas (1992a) On the communicative adjustment of perspectives, dialogue, and communicative genres. In A.H. Wald (ed), The dialogical altemative. Towards a theory of language and mind. London: Scandinavian University Press, 219-234.

Luckmann, Thomas (1992b) Rekonstruktive Gattungen. Manuscript. Universität Konstanz.

Malinowski, Bronislaw (1960) A scientific theory of culture and other essays. New York: Oxford University Press.

Montgomery, Martin (1991) Our tune: A study of a discourse Genre. In P. Scannell (ed.), Broadcast Talk. London: Sage, 138-177.

Miller, Carolyn R. (1984) Genre as social action. Quarterly Journal of Speech 70.151-167.

Mitchell-Kernan (1972) Signifying and marking: Two Afro-American speech acts. In J.J. Gumperz \& D. Hymes (eds.), Directions in sociolinguistics. The Ethnography of Communication. New York: Holt, Rinehart and Winston, 161-179.

Müller, Frank E. (1989) Lautstilistische Muster in Alltagstexten von Süditalienern. In V. Hinnenkamp \& M. Selting (eds.), Stil und Stilisierung. Tübingen: Niemeyer, 61-81.

Murray, Denise E. (1988) The context of oral and written language: A framework for mode and medium switching. Language in Society 17.351-373.

Oring, Elliott (1986) Folk narratives. In E. Oring (ed.), Folk groups and folk genres. Logan: Utah State University Press, 121-146.

Pomerantz, Anita (1984) Agreeing and disagreeing with assessments: Some features of preferred/dispreferred turn shapes. In J.M. Atkinson \& J. Heritage (eds.), Structures of social action: Studies in conversation analysis. Cambridge: Cambridge University Press, 57-101.

Propp, V. (1988) Morphology of the folktale. Austin: University of Texas Press.

Röhrich, Lutz (1988) Erzählforschung. In R.W. Brednich (ed.), Grundriß der Volkskunde. Berlin: Dietrich Reimer, 353-380.

Sacks, Harvey (1963) Sociological description. Berkeley Journal of Sociology 8.1-16.

Samarin, W.F. (1987) The language of religion. In U. Ammon, N. Dittmar \& K.J. Mattheier (eds.), Socioinguistics-Soziolinguistik, 1. Halbband. Berlin/ New York: de Gruyter, 85-91.

Sapir, Edward (1909) Wishram texts. Leiden: Publ. of the American Ethnological Society 2.

Schiffrin, Deborah (1984) Jewish argument as sociability. Language in Society 13.311-335. 
Schiffrin, Deborah (1987) Discourse markers. Cambridge: Cambridge University Press.

Schmitt, Reinhold (1992) Die Schwellenstehen - Sprachliche Präsenz und sozialer Austausch in einem Kiosk. Tübingen: Narr.

Schutz, Alfred (1962) Collected papers I: The problem of social reality. The Hague: Martinus Nijhoff.

Schutz, Alfred \& Thomas Luckmann (1973) Structures of the life-world. Vol. I. Evanston: Northwestern University Press.

Schutz, Alfred \& Thomas Luckmann (1989) Structures of the life-world. Vol. II. Evanston: Northwestern University Press.

Schulze, Gerhard (1992) Die Erlebnisgesellschaft. Kultursoziologie der Gegenwart. Frankfurt: Suhrkamp.

Seibert, Thomas-Michael (1991) Erzählen als gesellschaftliche Konstruktion von Kriminalität. In J. Schönert (ed.), Erzählte Kriminalität. Tübingen: Max Niemeycr, 73-86.

Selting, Margret (1992) Intonation as a contexualization device: Case studics on the role of prosody, especially intonation, in contextualizing story telling in conversation. In P. Aucr \& A. di Luzio (eds.), The contextualization of language. Amsterdam: Benjamins, 233-258.

Sherzer, Joel (1974) Namakke, sunmakke, kormakke: Three types of Cuna speech events. In R. Bauman \& J. Sherzer (eds.), Explorations in the ethnography of speaking. Cambridge: Cambridge University Press, 263-282.

Sherzer, Joel (1987) A discourse-centered approach to language and culture. American Anthropologist 89.295-309.

Silverstein, Michael (1985) Language and the culture of Gender: At the intersection of structure, usage and ideology. In E. Mertz \& R.J. Parmentier (eds.), Scmiotic meditation: Sociocultural and psychological perspectives. Orlando, etc.: Academic Press, 219-259.

Silverstein, Michael (1992) The uses and utility of ideology: Some reflections. Pragmatics 2:3.311324.

Silverstein, Michael (1993) Metapragmatic discourse and metapragmatic function. In J. Lucy (ed.), Reflexive language: Reported speech and metapragmatics. Cambridge: Cambridge University Press, 3358.

Sternfeld, Eva (1990) Die Frauenschrift aus Hunan. In A. Gerstlacher \& M. Miosga (eds.), China der Frauen. München: Frauenoffensive, 24-27.

Straehle, Carolyn A. (1993) 'Samuel' 'Yes, dear?' Teasing and conversational rapport. In D. Tannen (ed.), Framing in discourse. Oxford: Oxford University Press, 210-229.

Swales, Jahn M. (1990) Genre analysis. English in academic and research settings. Cambridge: Cambridge University Press.

Tannen, Deborah (1993) Framing in discourse. Oxford: Oxford University Press.

Thompson, Stith (1955-59) Motif-Index of Folk-Literature. Kopenhagen: Rosenkilde \& Bagger.

Ulmer, Bernd (1988) Konversionserzählungen: Strukturen und Funktionen einer rekonstruktiven 
Gattung. Zeitschrift für Soziologie 17:1.19-33.

Virtanen, Leea (1976) Paranormale Spontanerlebnisse in der modernen Erzähltradition. In J. Pentikäinen \& U.T. Juurikka (eds.), Folk-Research. Helsinki, 338-347.

Volosinov, Valentin N. (1929/1986) Marxism and the philosophy of language. Cambridge, Mass.: Harvard University Press.

Winkler, Peter (1986) Gattungsspezifik von Sprechhandlungen. In E. Slembek (ed.), Miteinander Sprechen und Handeln. Frankfurt: Scriptor, 331-341.

Wojcik, Daniel (1987/88) 'At the sound of the beep': An analysis of the structure and traditional speech forms of answering machines. Folklore and Mythology Studies 1987/88.81-103.

Wuthnow, Robert (1992) Rediscovering the sacred. Perpectives on religion in contemporary Society. Grand Rapids, Michigan: Wm. B. Eerdmans Publishing Co.

Yuan, Ji Feng, Koenraad Kuiper \& Shaogu Shu (1990) Language and revolution: Formulae of the Cultural Revolution. Language in Society 19.61-79.

Zaretsky, Irving, I. (1974) In the beginning was the word: The relationship of language to social organization in spiritualist churches. In I.I. Zaretsky \& M.P. Leone (eds.), Religious movements in contemporary America. Princeton, N.J.: Princeton Univ. Press, 168-221.

Zaretsky, Irving I. \& Mark P. Leone (1974) Introduction. In I.I. Zaretsky \& M.P. Leone (eds.), Religious movements in contemporary America. Princeton, N.J.: Princeton Univ. Press, XVII-XXXVI. 